Berkala Ilmu Perpustakaan dan Informasi, Vol. 13, No. 2, Desember 2017, Hal. 117-130 DOI: 10.22146/bip.27499

ISSN 1693-7740 (Print), ISSN 2477-0361 (Online)

Tersedia online di https://jurnal.ugm.ac.id/bip

\title{
PERAN FORUM PUSTAKAWAN DALAM PENGEMBANGAN PROFESIONALISME PUSTAKAWAN DI LINGKUNGAN UNIVERSITAS GADJAH MADA
}

\author{
Desy Natalia Anggorowati dan Roh Wahyu Widayati ${ }^{1}$ \\ ${ }^{1}$ Pustakawan Universitas Gadjah Mada \\ e-mail : desy_fkg@ugm.ac.id
}

Naskah diterima: 15 Agustus 2017, direvisi: 29 September 2017, disetujui: 13 Oktober 2017

\begin{abstract}
ABSTRAK
Penelitian ini membahas peran Forum Pustakawan UGM sebagai wadah pengembangan profesionalisme Pustakawan di lingkungan UGM. Tujuan penelitian ini untuk mengetahui peran Forum Pustakawan terhadap pengembangan profesionalisme dan kompetensi pustakawan serta untuk mengetahui faktor-faktor yang menghambat keinginan dari pustakawan untuk turut aktif melibatkan diri dalam Forum Pustakawan. Metode penelitian yang digunakan adalah deskriptif kualitatif dengan studi literatur dan wawancara. Hasil penelitian menunjukkan bahwa peran Forum Pustakawan dalam tiga periode kepengurusan terakhir yaitu tahun 20112013, 2013-2015, dan 2015-2018 dalam pengembangan profesionalisme Pustakawan di lingkungan UGM sudah dilaksanakan dengan baik dan mendukung empat kompetensi dalam SKKNI (Standar Kompetensi Kerja Nasional Indonesia). Dari 60 kegiatan yang telah dilaksanakan Forum Pustakawan, kompetensi inti "melakukan kegiatan literasi informasi" mendapat capaiaan paling tinggi. Sedangkan hambatan anggota dalam memanfaatkan Forum Pustakawan sebagai sarana pengembangan profesionalisme dan kompetensi adalah agenda kegiatan yang dilakukan Forum Pustakawan terkadang berbenturan dengan kegiatan atau tugas dinas lain, konten kegiatan yang dilakukan Forum Pustakawan tidak sesuai dengan kebutuhan anggota serta konten kegiatan yang dilaksanakan Forum Pustakawan bisa dipelajari sendiri.
\end{abstract}

Kata Kunci: Pustakawan, Profesionalisme, Kompetensi, Forum Pustakawan UGM

\section{ABSTRACT}

This research discusses the role of Librarian Forum at UGM. The purpose of this paper is to examine the role of Librarian Forum to develop professionalism and competence for librarians and to understand the inhibiting factors from librarians to actively involve themselves in the Forum. Using a descriptive qualitative approach, the data collection method was literature study and interviews. The result indicated that the role of Librarian Forum in the last 3 period: 2011-2013, 2013-2015 and 2015-2018 has been indicated important to support 4 competencies in SKKNI (Standar Kompetensi Kerja Nasional Indonesia). But of the 60 activities, the core competence of "conducting information literacy activities" showed the highest. Challenges faced by the members to utilise the Librarian Forum as a professional development arena and competence was the schedule. Another challenges were that, the content of activities didnot match with what the members needed.,

Keywords: Librarian, Professionalism, Competence, Librarian Forum UGM 


\section{A. PENDAhULUAN}

Sebagai wadah komunikasi dan pengembangan karir profesi pustakawan di lingkungan Universitas Gadjah Mada, dibentuk sebuah forum yaitu Forum Pustakawan UGM (FP). Pada setiap periode kepengurusan, peran dan tugas FP tertuang dalam Surat Keputusan Kepala Perpustakaan UGM. Peran dan tugas Forum tersebut, antara lain: menyusun rencana kegiatan selama periode kepengurusan, menyelenggrakan kegiatan untuk meningkatkan kualitas sumber daya manusia kepustakawanan, menciptakan iklim kerja kepustakawanan yang kondusif dengan didukung oleh sikap profesional pustakawan dan melaporkan kegiatan FP kepada Kepala Perpustakaan.

Mengacu program-program dan kegiatan yang diselenggarakan dalam setiap periode kepengurusan, FP UGM telah memberikan kemajuan yang positif bagi peningkatan dan pengembangan profesionalisme anggotanya. Namun demikian terdapat beberapa hal yang perlu mendapatkan perhatian secara serius dari pengurus, seperti: tingkat partisipasi dan keaktifan anggota terhadap program serta ketepatan program terhadap kebutuhan peningkatan profesionalisme anggota. Indikasi ketidaktepatan program dengan paramater seperti adanya satu kegiatan dengan sasaran peserta diluar anggota, menimbulkan pertanyaan, sebesar apa anggota dapat mengambil manfaat langsung dari kegiatan yang diselenggarakan FP.

Kondisi di atas menjadi pertimbangan peneliti untuk melakukan suatu kajian terkait bagaimana peran FP terhadap pengembangan profesionalisme dan kompetensi Pustakawan di lingkungan UGM dan faktor-faktor apa saja yang menghambat keinginan dari para pustakawan untuk turut aktif melibatkan diri dalam forum.

Tujuan penelitian ini adalah untuk mengetahui peran FP UGM terhadap pengembangan profesionalisme dan kompetensi pustakawan di UGM serta untuk mengetahui faktor-faktor apa saja yang menghambat keinginan pustakawan untuk turut aktif melibatkan diri dalam forum tersebut.
Hasil penelitian ini diharapkan dapat memberikan masukan bagi FP UGM dalam melakukan penyusunan program kerja yang lebih konstruktif sesuai dengan kebutuhan profesionalisme dan kompetensi pustakawan. Manfaat lain, hasil penelitian dapat menjadi acuan dan masukan bagi pengambil kebijakan khususnya Manajemen Perpustakaan UGM dalam supporting terhadap keberlangsungan FP UGM, serta sebagai masukan dan alat bagi pustakawan di UGM untuk terus turut aktif dalam memanfaatkan keberadaan forum ini guna peningkatan mutu profesionalisme dan kompetensi para Pustakawan.

\section{B. TINJAUAAN PUSTAKA \\ a. Profesionalisme}

Profesionalisme menurut Kamus Besar Bahasa Indonesia adalah mutu, kualitas, dan tindak tanduk yang merupakan ciri suatu profesi atau orang profesional (Departemen Pendidikan dan Kebudayaan, 2011). Sikap profesional meliputi lima komponen, yaitu: (1) sikap mementingkan kepuasan pemakai, (2) sikap efisien dan ekonomis, (3) sikap disiplin, (4) sikap selalu berupaya meningkatkan serta mengembangkan pengetahuan dan keterampilan di bidangnya, serta (5) sikap senantiasa memelihara rasa kesejawatan dengan teman-teman yang seprofesi.

\section{b. Profesi Pustakawan}

Dalam Kamus Besar Bahasa Indonesia, profesi memiliki arti kata pekerjaan atau sebuah sebutan pekerjaan, terutama pekerjaan yang memerlukan pendidikan atau latihan (Departemen Pendidikan dan Kebudayaan, 2011). Sebuah Profesi berkaitan dengan sikap professional, artinya segala sesuatu yang berkaitan dengan profesi.

Adapun ciri-ciri profesi sebagai berikut: (a) suatu jabatan yang memiliki fungsi dan signifikansi sosial yang menentukan (crusial), (b) jabatan yang menuntut keterampilan/ keahlian tertentu, (c) keterampilan/ keahlian yang dituntut jabatan itu dapat melalui pemecahan masalah dengan menggunakan teori dan metode ilmiah, (d) jabatan itu berdasarkan pada batang tubuh disiplin ilmu yang jelas, 
sistematik, dan eksplisit yang bukan hanya sekedar pendapat khalayak umum, (e) jabatan itu memerlukan pendidikan tingkat perguruan tinggi dengan waktu yang cukup lama, (f) proses pendidikan untuk jabatan itu juga merupakan aplikasi dan sosialisasi nilai-nilai profesional itu sendiri, (g) dalam memberikan layanan kepada masyarakat anggota profesi berpegang teguh pada kode etik yang dikontrol oleh organisasi profesi, (h) tiap anggota profesi mempunyai kebebasan dalam memberikan judgement terhadap permasalahan profesi yang dihadapinya, (i) dalam prakteknya melayani masyarakat, anggota profesi otonom dan bebas dari campur tangan orang luar, (j) jabatan ini mempunyai prestise yang tinggi dalam masyarakat, dan oleh karenanya memperoleh imbalan yang tinggi (Sanusi, 1991).

Profesi Pustakawan sebagaimana yang termaktub dalam dalam Undang-Undang RI Nomor 43 Tahun 2007 Bab Pasal 1 Ayat 8 yang menyatakan bahwa Pustakawan adalah "seseorang yang memiliki kompetensi yang diperoleh melalui pendidikan dan atau pelatihan kepustakawanan serta mempunyai tugas dan tanggung jawab untuk melaksanakan pengelolaan dan pelayanan Perpustakaan".

Sulistyo-Basuki (2004) mendefinisikan profesi Pustakawan mempunyai ciri sebagai berikut: 1) adanya sebuah asosiasi atau organisasi keahlian; 2) adanya struktur dan pola pendidikan yang jelas; 3) adanya kode etik; 4) adanya tingkat kemandirian; 5) profesi Pustakawan berorientasi pada jasa.

\section{c. Profesionalisme dan Kompetensi Pustakawan}

Profesionalisme Pustakawan mengandung arti bahwa segala pelaksanaan kegiatan harus bermutu dan berkualitas. Pustakawan harus mempunyai tanggung jawab dan mampu memecahkan masalah yang tak dapat dipecahkan orang lain. Tanggung jawab Pustakawan tak sekedar melakukan tugas-tugas rutin berkaitan dengan buku, namun juga kegiatan bermutu yang hasilnya dapat dipertanggungjawabkan sesuai prosedur kerja.

Pengembangan karir serta profesionalisme Pustakawan Indonesia telah diatur dalam
SKKNI (Standar Kompetensi Kerja Nasional Indonesia) bidang Perpustakaan. Standar ini disusun sesuai dengan amanah Undang-Undang Nomor 43 Tahun 2007 tentang Perpustakaan, yang di dalamnya mengatur tentang perpustakaan dan pustakawan. Dalam undangundang ini disebutkan bahwa Pustakawan adalah seseorang yang memiliki kompetensi yang diperoleh melalui pendidikan dan/ atau pelatihan kepustakawanan serta mempunyai tugas dan tanggung jawab untuk melaksanakan pengelolaan dan pelayanan perpustakaan. Dalam Pasal 29, ayat (1) disebutkan bahwa tenaga perpustakaan terdiri atas pustakawan dan tenaga teknis perpustakaan; dan dipertegas dalam ayat (2) bahwa, pustakawan sebagaimana dimaksud pada ayat (1) harus memenuhi kualifikasi sesuai dengan Standar Nasional Perpustakaan.

Di dalam SKKNI disebutkan bahwa kompetensi adalah kemampuan seseorang yang mencakup pengetahuan, keterampilan dan sikap kerja yang dapat terobservasi dalam menyelesaikan suatu pekerjaan atau tugas sesuai dengan standar kinerja yang ditetapkan. Pengetahuan dan keterampilan diwujudkan dalam 3 (tiga) kelompok unit kompetensi, yaitu kelompok kompetensi umum, kelompok kompetensi inti, dan kelompok kompetensi khusus dan kelompok kompetensi kunci.

Kompetensi umum adalah kompetensi dasar yang harus dimiliki oleh setiap Pustakawan, diperlukan untuk melakukan tugas-tugas perpustakaan, meliputi: (1) mengoperasikan komputer tingkat dasar, kompetensi ini merupakan kemampuan yang didasari atas pengetahuan, ketrampilan dan sikap kerja yang dibutuhkan untuk mengoperasikan komputer guna mendukung pelaksanaan tugas-tugas di perpustakaan. (2) menyusun rencana kerja perpustakaan, yaitu kemampuan yang didasari atas pengetahuan, ketrampilan dan sikap kerja yang dibutuhkan untuk menyusun rencana kerja perpustakaan. (3) membuat laporan kerja perpustakaan, yaitu kemampuan yang didasari atas pengetahuan, ketrampilan dan sikap kerja yang dibutuhkan untuk membuat laporan kerja perpustakaan. Kompetensi umum ini melekat dalam kompetensi inti dan khusus. Kompetensi 
inti adalah kompetensi fungsional yang harus dimiliki oleh setiap Pustakawan dalam menjalankan tugas-tugas Perpustakaan. Kompetensi inti mencakup unit-unit kompetensi yang dibutuhkan untuk mengerjakan tugas-tugas inti dan wajib dikuasai oleh Pustakawan.

Kompetensi inti meliputi: (1) melakukan seleksi bahan perpustakaan, kompetensi ini merupakan kemampuan yang didasari atas pengetahuan, ketrampilan dan sikap kerja yang dibutuhkan untuk menyeleksinbahan perpustakaan sebagai bagian dari pengembangan koleksi. (2) melakukan pengadaan bahan perpustakaan, kompetensi ini merupakan kemampuan yang didasari atas pengetahuan, ketrampilan dan sikap kerja yang dibutuhkan untuk mengadakan bahan perpustakaan sebagai bagian dari pengembangan koleksi. (3) melakukan pengatalogan deskriptif, kompetensi ini merupakan kemampuan yang didasari atas pengetahuan, ketrampilan dan sikap kerja yang dibutuhkan untuk melakukan pengatalogan deskriptif sebagai bagian dari pengolahan bahan perpustakaan. (4) melakukan pengatalogan subyek, kompetensi ini merupakan kemampuan yang didasari atas pengetahuan, ketrampilan dan sikap kerja yang dibutuhkan untuk melakukan pengatalogan subyek sebagai bagian dari pengolahan bahan perpustakaan. (5) melakukan perawatan bahan perpustakaan, kompetensi ini merupakan kemampuan yang didasari atas pengetahuan, ketrampilan dan sikap kerja yang dibutuhkan untuk melakukan perawatan bahan pustaka. (6) melakukan layanan sirkulasi, kompetensi ini merupakan kemampuan yang didasari atas pengetahuan, ketrampilan dan sikap kerja yang dibutuhkan untuk melakukan layanan sirkulasi termasuk silang layan perpustakaan (7) melakukan layanan referensi, kompetensi ini merupakan kemampuan yang didasari atas pengetahuan, ketrampilan dan sikap kerja yang dibutuhkan untuk melakukan kegiatan layanan referensi, termasuk memanfaatkan jejaring informasi. (8) melakukan penelusuran informasi sederhana, kompetensi ini merupakan kemampuan yang didasari atas pengetahuan, ketrampilan dan sikap kerja yang dibutuhkan untuk melakukan layanan penelusuran informasi sederhana untuk pemustaka di perpustakaan. (9) melakukan promosi perpustakaan, kompetensi ini berhubungan dengan pengetahuan, ketrampilan dan sikap kerja yang dibutuhkan untuk memperkenalkan, menyebarluaskan dan mendayagunakan sumber daya serta layanan perpustakaan kepada masyarakat. (10) melakukan kegiatan literasi informasi, kompetensi ini berhubungan dengan pengetahuan, ketrampilan dan sikap kerja yang dibutuhkan untuk melakukan kegiatan literasi informasi. (11) memanfaatkan jaringan internet untuk layanan perpustakaan, kompetensi ini berhubungan dengan pengetahuan, ketrampilan dan sikap kerja yang dibutuhkan dalam menggunakan jaringan internet untuk melayani pemustaka.

Kompetensi khusus merupakan kompetensi tingkat lanjut yang bersifat spesifik, meliputi: (1) merancang tata ruang dan perabot perpustakaan, kompetensi ini merupakan kemampuan yang didasari atas pengetahuan, ketrampilan dan sikap kerja yang dibutuhkan untuk merancang tata ruang dan perabot yang sesuai dengan kebutuhan perpustakaan dan pemustaka. (2) melakukan perbaikan bahan perpustakaan, kompetensi ini berhubungan dengan pengetahuan, ketrampilan dan sikap kerja yang dibutuhkan untuk melakukan perbaikan bahan perpustakaan, meliputi fisik dan isi dokumen. (3) membuat literatur sekunder, kompetensi ini berhubungan dengan pengetahuan, ketrampilan dan sikap kerja yang dibutuhkan untuk membuat literatur sekunder yang siap digunakan sesuai kebutuhan pemustaka. (4) melakukan penelusuran informasi kompleks, kompetensi ini merupakan kemampuan yang didasari atas pengetahuan, ketrampilan dan sikap kerja yang dibutuhkan untuk melakukan kegiatan layanan penelusuran informasi khusus tentang suatu subyek dengan menggunakan sarana temu kembali informasi yang tersedia di dalam atau di luar perpustakaan. (5) melakukan kajian perpustakaan, kompetensi ini berhubungan dengan pengetahuan, ketrampilan dan sikap kerja yang dibutuhkan untuk melakukan kajian bidang perpustakaan. 
(6) membuat karya tulis ilmiah, kompetensi ini merupakan kemampuan yang didasari atas pengetahuan, ketrampilan dan sikap kerja yang dibutuhkan untuk membuat karya tulis ilmiah di bidang perpustakaan.

Kompetensi kunci merupakan persyaratan kemampuan yang harus dimiliki seseorang untuk mencapai unjuk kerja yang dipersyaratkan dalam pelaksanaan tugas pada unit kompetensi tertentu yang terdistribusi dalam tujuh kriteria kompetensi kunci, antara lain: (1) mengumpulkan, menganalisis dan mengorganisasikan informasi. (2) mengkomunikasikan informasi dan ide-ide. (3) merencanakan dan mengorganisasikan kegiatan. (4) bekerjasama dengan orang lain dan kelompok. (5) menggunakan gagasan secara sistematis dan teknis. (6) memecahkan masalah. (7) menggunakan teknologi. 7 (tujuh) kompetensi kunci memiliki tingkatan dalam tiga kategori, yaitu: tingkat 1 (satu) melakukan kegiatan, tingkat 2 (dua) mengelola kegiatan dan tingkat 3 (tiga) mengevaluasi dan memodifikasi proses. Tingkatan (gradasi) kompetensi kunci ini digunakan sebagai indikator untuk menentukan kompetensi Pustakawan.
Tabel.1. Gradasi (Tingkatan) Kompetensi Kunci

\begin{tabular}{|c|c|c|c|}
\hline $\begin{array}{l}\text { Kompetensi } \\
\text { Kunci }\end{array}$ & $\begin{array}{l}\text { Tingkat 1 } \\
\text { Melakukan } \\
\text { Kegiatan } \\
\end{array}$ & $\begin{array}{l}\text { Tingkat 2 } \\
\text { Mengelola } \\
\text { Kegiatan } \\
\end{array}$ & $\begin{array}{l}\text { Tingkat } 3 \\
\text { Mengevaluasi dan } \\
\text { Memodifikasi Proses } \\
\end{array}$ \\
\hline $\begin{array}{l}\text { Mengumpulkan, } \\
\text { Menganalisis dan } \\
\text { Mengorganisasikan } \\
\text { Informasi }\end{array}$ & $\begin{array}{l}\text { Mengikuti pedoman } \\
\text { yang ada dan } \\
\text { merekam dari satu } \\
\text { sumber informasi }\end{array}$ & $\begin{array}{l}\text { Mengakses dan } \\
\text { merekam lebih } \\
\text { dari satu sumber } \\
\text { informasi }\end{array}$ & $\begin{array}{l}\text { Meneliti dan } \\
\text { menyaring lebih dari } \\
\text { satu sumber dan } \\
\text { mengevaluasi kualitas } \\
\text { informasi }\end{array}$ \\
\hline $\begin{array}{l}\text { Mengkomunikasi } \\
\text { kan Informasi dan } \\
\text { Ide-ide }\end{array}$ & $\begin{array}{l}\text { Menerapkan bentuk } \\
\text { komunikasi untuk } \\
\text { mengantisipasi } \\
\text { kontek komunikasi } \\
\text { sesuai jenis dan gaya } \\
\text { berkomunikasi }\end{array}$ & $\begin{array}{l}\text { Menerapkan } \\
\text { gagasan } \\
\text { informasi dengan } \\
\text { memilih gaya } \\
\text { yang paling } \\
\text { sesuai }\end{array}$ & $\begin{array}{l}\text { Memilih model dan } \\
\text { bentuk yang sesuai } \\
\text { dan memperbaiki dan } \\
\text { mengevaluasi jenis } \\
\text { komunikasi dari } \\
\text { berbagai macam jenis } \\
\text { dan gaya cara } \\
\text { berkomunikasi }\end{array}$ \\
\hline $\begin{array}{l}\text { Merencanakan dan } \\
\text { Mengorganisasikan } \\
\text { Kegiatan }\end{array}$ & $\begin{array}{l}\text { Bekerja dibawah } \\
\text { pengawasan atau } \\
\text { supervisi }\end{array}$ & $\begin{array}{l}\text { Mengkoordinir } \\
\text { dan mengatur } \\
\text { proses pekerjaan } \\
\text { dan menetapkan } \\
\text { prioritas kerja }\end{array}$ & $\begin{array}{l}\text { Menggabungkan } \\
\text { strategi, rencana, } \\
\text { pengaturan, tujuan } \\
\text { dan prioritas kerja }\end{array}$ \\
\hline $\begin{array}{l}\text { Bekerjasama dengar } \\
\text { Orang Lain dan } \\
\text { Kelompok }\end{array}$ & $\begin{array}{l}\text { nelaksanakan } \\
\text { kegiatan-kegiatan } \\
\text { yang sudah } \\
\text { dipahami/aktifitas } \\
\text { rutin }\end{array}$ & $\begin{array}{l}\text { Melaksanakan } \\
\text { kegiatan dan } \\
\text { membantu } \\
\text { merumuskan } \\
\text { tujuan }\end{array}$ & $\begin{array}{l}\text { Bekerjasama untuk } \\
\text { menyelesaikan } \\
\text { kegiatan-kegiatan } \\
\text { yang bersifat komplek }\end{array}$ \\
\hline $\begin{array}{l}\text { Menggunakan } \\
\text { Gagasan Secara } \\
\text { Sistematis dan } \\
\text { Teknis }\end{array}$ & $\begin{array}{l}\text { Melaksanakan tugas- } \\
\text { tugas yang sederhana } \\
\text { dan telah ditetapkan }\end{array}$ & $\begin{array}{l}\text { Memilih gagasan } \\
\text { dan teknik } \\
\text { bekerja yang } \\
\text { tepat untuk } \\
\text { menyelesaikan } \\
\text { tugas-tuga yang } \\
\text { komplek }\end{array}$ & $\begin{array}{l}\text { Bekerjasama dalam } \\
\text { menyelesaikan tugas } \\
\text { yang lebih komplek } \\
\text { dengan menggunakan } \\
\text { teknik dan matematis }\end{array}$ \\
\hline $\begin{array}{l}\text { Memecahkan } \\
\text { Masalah }\end{array}$ & $\begin{array}{l}\text { Memecahkan } \\
\text { masalah untuk tugas } \\
\text { rutin di bawah } \\
\text { pengawasan/super } \\
\text { visi }\end{array}$ & $\begin{array}{l}\text { Memecahkan } \\
\text { masalah untuk } \\
\text { tugas rutin secara } \\
\text { mandiri } \\
\text { berdsarkan } \\
\text { pedoman/pandu } \\
\text { an }\end{array}$ & $\begin{array}{l}\text { Memecahkan masalah } \\
\text { yang kompllek } \\
\text { dengan menggunakan } \\
\text { pendekatan metoda } \\
\text { yang sistimatis }\end{array}$ \\
\hline $\begin{array}{l}\text { Menggunakan } \\
\text { Teknologi }\end{array}$ & $\begin{array}{l}\text { Menggunakan } \\
\text { teknologi untuk } \\
\text { membuat barang dan } \\
\text { jasa yang sifatnya } \\
\text { berulang-ulang pada } \\
\text { tingkat dasar di } \\
\text { bawah } \\
\text { pengawasan/ } \\
\text { supervisi } \\
\end{array}$ & $\begin{array}{l}\text { Menggunakan } \\
\text { teknologi untuk } \\
\text { mengkonstruksi, } \\
\text { mengorganisasi } \\
\text { kan / membuat } \\
\text { produk barang } \\
\text { atau jasa } \\
\text { berdasarkan } \\
\text { desain } \\
\end{array}$ & $\begin{array}{l}\text { Menggunakan } \\
\text { teknologi untuk } \\
\text { membuat } \\
\text { desain/merancang } \\
\text { menggabungkan, } \\
\text { memodifikasi dan } \\
\text { mengembangkan } \\
\text { produk barang atau } \\
\text { jasa }\end{array}$ \\
\hline
\end{tabular}


Adapun profesionalisme Pustakawan menurut Istiana (2011) mengandung arti pelaksanaan kegiatan yang didasarkan pada keahlian, rasa tanggung jawab dan pengabdian, serta kualitas hasil kerja yang tidak dapat dihasilkan oleh tenaga yang bukan pustakawan. Pustakawan harus selalu berusaha mengembangkan kemampuan dan keahliannya untuk memberikan hasil kerja yang bermutu dan berkontribusi besar terhadap pemenuhan kebutuhan akan informasi dan pengetahuan dari masyarakat yang dilayani.

Ada beberapa hal penting yang harus diperhatikan dan hendaknya menjadi komitmen pustakawan untuk meningkatkan profesionalismenya yaitu:

1. Bekerja berdasarkan ilmu.

2. Memiliki kemampuan intrapersonal seperti: memiliki tanggung jawab, mampu mengenali perasaannya, dan mengarahkan emosi pribadinya, mempunyai kepercayaan diri, berani mengambil keputusan, mampu memotivasi diri-sendiri, mampu mengintropeksi diri dan memperbaiki kekurangannya.

3. Memiliki kemampuan interpersonal seperti: kemampuan interpersonal berkaitan dengan kemampuan seseorang berinteraksi dengan orang lain dan membangun hubungan baik dengan individu lain.

Menurut Nashihuddin \& Aulianto (2015) beberapa strategi yang perlu dilakukan oleh Pustakawan untuk meningkatkan kompetensi dan profesionalisme kerjanya yaitu: (1) me n ingkatkan kin erja s e cara berkesinambungan, (2) membangun komunikasi internal secara efektif, (3) menggagas ide-ide inovatif Perpustakaan, (4) mengikuti program sertifikasi Pustakawan, dan (5) melakukan pengembangan karier profesional.

Peningkatan profesionalisme pustakawan terimplementasi dalam suatu program-program dan kegiatan yang dikemas dalam bentukbentuk kegiatan seperti :

1. Pelatihan bidang Pusdokinfo.

2. Pelatihan peningkatan kompetensi Pustakawan (kemampuan interpersonal/ soft skill dan penguasaan teknologi informasi.

3. Pertemuan-pertemuan ilmiah Pustakawan secara berkelanjutan di bidang Pusdokinfo yang dilakukan secara berkala. Materi disampaikan secara bergantian dan wajib membuat karya ilmiah untuk dipresentasikan (Perpustakaan IPB, 2009)

\section{a. Forum Pustakawan UGM}

Forum sejatinya dapat dikategorikan sebagai suatu bentuk organisasi, oleh karena itu perlu diketahui definisi dan ruang lingkup organisasi.

Definisi organisasi sangat beragam, selain itu orientasi definisi maupun fokusnya juga berbeda-beda. Mahsun (2006) menjelaskan bahwa organisasi sering dipahami sebagai kelompok orang yang berkumpul dan bekerja sama dengan cara yang terstruktur untuk mencapai tujuan atau sejumlah sasaran tertentu yang telah ditetapkan bersama. Tidak jauh berbeda dengan definisi di atas, Robbins \& Judge (2008) menyatakan bahwa organisasi adalah sebuah unit sosial yang dikoordinasi secara sadar, terdiri atas dua individu atau lebih, dan berfungsi dalam suatu dasar yang relatif terus-menerus guna mencapai satu atau serangkaian tujuan bersama.

Selain itu, Sulistiyani \& Rosidah (2009) menjelaskan definisi organisasi dengan mengklasifikasikan definisi organisasi menjadi tiga, yaitu:

1. Organisasi dipandang sebagai kumpulan orang

2. Organisasi dipandang sebagai proses pembagian kerja

3. Organisasi dipandang sebagai sistem

Dari beberapa definisi organisasi di atas, maka organisasi adalah sekumpulan orang yang terkoordinasi untuk melakukan kegiatankegiatan untuk mencapai tujuan yang telah ditetapkan bersama.

Adapun pengertian dari forum itu sendiri, menurut Departemen Pendidikan dan Kebudayaan (2011) adalah wadah atau tempat pertemuan sebuah komunitas yang memiliki persamaan minat dan tujuan untuk bertukar 
pikiran suatu topik atau masalah secara bebas yang berkaitan dengan forum tersebut.

Seperti yang diungkapkan oleh Wijayati (2013), makna forum adalah sebuah wadah yang disediakan untuk berinteraksi bagi para penggunanya dimana para pengguna lebih dimudahkan dalam mencari informasi sesuai dengan kategori-kategori yang diberikan dalam sebuah forum.

Dari beberapa definisi terkait forum tersebut, bahwa FP UGM adalah suatu wadah yang dibentuk untuk memfasilitasi segala kegiatan dan bertujuan untuk mengembangkan kapabilitas dan profesionalisme pustakawan UGM.

Peran forum ini dalam melakukan peningkatan terhadap kemampuan para anggotanya, tentunya harus memiliki alat ukur yang jelas sehingga hasil yang akan dicapai tepat sesuai dengan yang telah direncanakan. Maka perlu adanya pengukuran terhadap kinerja dari forum itu sendiri.

Atmosudirdjo dalam Pasolong (2010) mengemukakan bahwa kinerja organisasi adalah efektivitas organisasi secara menyeluruh untuk kebutuhan yang ditetapkan dari setiap kelompok yang berkenaan melalui usaha-usaha yang sistemik dan meningkatkan kemampuan organisasi secara terus-menerus untuk mencapai kebutuhannya secara efektif.

Bila dikaitkan dengan forum sebagai sebuah organisasi, tentunya kinerja suatu forum akan dipengaruhi oleh banyak faktor, termasuk posisi strategis, struktur pengurus, proses sumber daya manusia, dan yang paling penting adalah perlunya penentuan terhadap strategi, tujuan, dan integrasi yang jelas. Karena strategi merupakan integrasi rencana untuk mencapai tujuan organisasi, maka semua faktor atau variabel dalam tubuh organisasi saling berhubungan dan berkontribusi untuk menghasilkan kinerja organisasi. Namun kesemua faktor atau variabel tersebut telah dipengaruhi oleh lingkungan internal dan eksternal sebelum memberikan pengaruh pada kinerja organisasi.

Menurut (Mahmudi, 2010) bahwa kinerja organisasi pada dasarnya terkait dengan kinerja individu dan kinerja tim. Sehingga apabila dalam organisasi setiap individu dan tim bekerja dengan baik, berprestasi dan memberikan kontribusi terbaiknya terhadap organisasi, maka kinerja organisasi secara keseluruhan akan baik. Selain kinerja individu dan kinerja tim, faktor lingkungan baik intenal maupun eksternal juga memiliki andil terhadap kinerja organisasi.

Dari berbagai definisi kinerja di atas, bahwa untuk mencapai kinerja yang maksimal dari sebuah organisasi maka sangat diperlukan peran dari semua pihak baik itu pengurus maupun anggota Pustakawan di lingkungan UGM guna meningkatnya profesionalisme dan kompetensi dari Pustakawan UGM.

\section{METODE PENELITIAN}

Penelitian ini adalah penelitian deskriptif dengan metode kualitatif. Total sampel pada penelitian ini adalah delapan informan, yang terdiri dari: tiga pengurus FP UGM dengan tujuan ingin mengetahui program kegiatan selama kepengurusannya serta lima informan dari anggota FP. Tiga informan anggota FP terpilih berdasarkan pertimbangan akan kiprah dan pengalaman mereka di dunia kepustakawanan dan partisipasi aktif mereka dalam kegiatan yang diselenggarakan forum. Sedangkan dua orang informan anggota FP lainnya, terpilih atas pertimbangan bahwa informan ini tidak aktif di kegiatan forum akan tetapi kiprah di dunia kepustakawanan cukup aktif.

Pengumpulan data dalam penelitian ini melalui observasi dengan tujuan untuk mengetahui tentang konsep pengembangan yang dimiliki oleh FP dalam meningkatkan profesionalisme dan kompetensi para anggotanya, wawancara untuk memperkuat data, serta studi pustaka dilakukan pada penelitian ini yaitu melalui literatur buku, arsip, panduan, daftar kegiatan FP untuk mendukung data yang diperlukan.

Penelitian ini menggunakan metode analisis kualitatif dari hasil wawancara. Analisis data dari hasil wawancara selama dilapangan menggunakan model Miles and Huberman. Adapun aktivitas dalam analisis data yaitu:

1. Pengumpulan data (data collection)

2. Reduksi data(data reduction) 
3. Penyajian data (data display)

4. Penarikan kesimpulan (conclusion drawing/ verification) (Sugiyono, 2008).

\section{HASIL DAN PEMBAHASAN \\ a. Program kerja FP UGM}

Berdasarkan laporan pertanggungjawaban yang telah di susun oleh pengurus FP UGM khususnya pada periode kepengurusan 2011 2013, 2013-2015 dan 2015-2018 maka diketahui bahwa masing-masing periode kepengurusan telah melaksanakan berbagai macam kegiatan yang bertujuan untuk pengembangan terhadap kapasitas dan kapabilitas tiap-tiap anggota FP UGM. Adapun jenis-jenis kegiatan yang dimaksud adalah sebagai berikut:

Periode kepengurusan 2011-2013

1. Tiga seminar dengan tema "E-Content: Digital Resources for Academic and Learning", "Menyongsong Era Baru Sertifikasi Pustakawan", dan "Webometric".

2. Tujuh diskusi dengan tema "Kiprah Pustakawan ditingkat Nasional dan Internasional", "Kepustakawanan Indonesia", "Manajemen Sistem Informasi Perpustakaan: Belajar dari Pengalaman Jepang dan Indonesia", "Apresiasi Pustakawan UGM: Benchmarking Malaysia", "Kiprah Pustakawan Yogyakarta dalam berkompetisi", "Implementasi Angka Kredit Pustakawan", dan "Strategi Meraih Hibah Penelitian"

3. Final lecture dengan tema "Tren Pengembangan Perpustakaan".

4. Dua workshop dengan tema "Pemberkasan Angka Kredit: Tingkat Terampil", dan "Pemberkasan Angka Kredit: Tingkat Ahli".

5. Dua benchmarking dengan tujuan Perpustakaan Tinggi Malaysia dan Perpustakaan Indonesia UNIBRAW, serta Perpustakaan Proklamator Bung Karno Blitar.

6. Lima kali pengiriman duta pada kegiatan Seminar "Plagiarisme", "Knowledge Sharing: Sinergi dan Inovasi Jaringan Perpustakaan", "Profesionalisme dan Kepustakawanan", "Internet Sehat", serta
"Membangun jejaring, meningkatkan profesionalisme"

Periode kepengurusan 2013-2015

1. Empat talkshow kepustakawanan dengan tema "Menterjemahkan Kerja Kepustakawanan dalam Angka Kredit dan Sertifikasi", "Membangun Repositori Institusi dalam Kerangka Dokumentasi dan Diseminasi Karya Intelktual Anak Bangsa", "Sosialisasi Sasaran Kinerja Pegawai (SKP) dan Permenpan Nomor 09 Tahun 2014 ", serta "Strategi Pengembangan Diri Pustakawan".

2. Sosialisasi Keputusan Bersama Kepala Perpustakaan Nasional RI dan Kepala BKN Nomor 23 Tahun 2003 dan Nomor 21 Tahun 2003.

3. Workshop "Metodologi Penelitian Perpusdokinfo"

4. Delapan bedah buku dengan judul "Pendidikan Yang Menyenangkan", "Untold Story Susi Pudjiastuti", "Krisis Paradoks Film Indonesia", "Wonderful Family", "Melukis Surga", "Kebangkitan Etnis Menuju Politik Identitas", "Islam Isme-isme", "Profesi Pustakawan Menghadapi Tantangan Perubahan", serta "Reproduksi dan Obstetrik pada Kucing"

5. Tujuh kali pengiriman duta pada seminar PD IPI LIPI DIY "Sertifikasi”, "Dialog Ilmiah Perpustakaan FPPTI DIY: Repositori Institusi", "Workshop Saatnya Menjadi Penulis", "Seminar Diseminasi dan Plagiarisme", "Seminar "Digitalisasi dan Resources Sharing", "Seminar Nasional Multitasking Librarian", serta "Seminar Akreditasi Perpustakaan".

Periode kepengurusan 2015-2018

1. Dua diskusi ilmiah dengan tema: "Mengoptimalkan Potensi Perpustakaan dan Pustakawan Perguruan Tinggi" dan "Evaluasi e-Resources".

2. Sembilan workshop dengan tema: "How to Improve Your Spoken English in the Shortest Time Possible", "Manajemen Komplain", "Google Drive untuk Pustakawan dan 
Tenaga Perpustakaan UGM", "Peningkatan Kemampuan Penulisan Proposal Penelitian untuk Pustakawan: Menggali Ide Penulisan Proposal Penelitian", "Penelusuran Database Tingkat Lanjut", "Implementasi Permenpan Nomor 9 Tahun 2014 tentang Jabatan Fungsional Pustakawan dan Angka Kreditnya", "Penggunaan Summon dan Scopus", "Introduction to EEWOWW: a Tool Support Research Best Practices, serta Tips dan Trik Untuk Menulis di Jurnal Internasional.

3. Enam workshop Series Jurnal OnlineStrategi Penelusuran dan Reference Management Tools: "Wiley, ProquestCABI", "ACS PUb, AIP/APS, ASCE, ASME, SIAM", "Sage, Emerald, Cambridge \& Project Muse", "Springer, Oxford, $i$ Thenticate", serta "EBSCO"

4. Seminar nasional kepustakawanan dengan tema "Penguatan Kolaborasi Lintas Profesi untuk Peningkatan Akses Informasi dan Visibilitas Institusi".

5. Empat kali pengiriman duta pada "Seminar Literasi Informasi Keberlangsungannya Dari Sekolah Sampai Perguruan Tinggi”, "Seminar Peran Perpustakaan Dalam Tri Dharma Perguruan Tinggi", "Seminar Membangun dan Strategi Meningkatkan Peringkat Institutional Repository, dan "Pelatihan Mendeley FPPTI DIY".

\section{b. Hambatan Anggota}

Berdasarkan hasil wawancara yang telah dilakukan dengan lima informan anggota FP UGM, masing-masing Informan menyatakan bahwa hambatan dari anggota untuk turut aktif melibatkan diri dalam hal memanfaatkan FP UGM sebagai sarana pengembangan profesionalisme dan kompetensinya adalah:

Menurut Informan 1 "Kegiatan FP UGM sering saya ikuti sepanjang tidak bersamaan dengan agenda di Universitas, karena berprinsip segala sesuatu adalah ilmu" Sedangkan menurut Informan 2 "Sepanjang dengan tidak berbenturan dengan kegiatan lain, saya akan mengikuti dan terbuka, apapun temanya" . Adapun Informan 3 berpendapat bahwa "Saya akan mengikuti jika tidak bersamaan dengan acara lain karena untuk pengembangan diri sendiri, dari yang tidak tahu menjadi tahu" informan 3

Berbeda dengan pendapat 3 Informan diatas, menurut Informan 4 "Peranan FP UGM dalam mengembangkan profesionalisme dan kompetensi pustakawan melalui programprogram dan kegiatan yang diselenggarakan sudah bagus, namun demikian kegiatan belum menyentuh kepada kemampuan dan skills yang dapat diimplementasikan pustakawan pada tugas keseharian yang merupakan TUPOKSI pustakawan. Kegiatan FP UGM belum dapat mendongkrak kemampuan dan skill pustakawan. Kegiatan terkait informasiinformasi dan pengetahuan-pengetahuan tentang kompetensi inti pustakawan belum tersentuh sama sekali, sebagai contoh dalam manajemen koleksi, Perpustakaan UGM belum memiliki pedoman atau standar baku yang digunakan dalam pengelolaan pustaka (resources) baik cetak maupun digital. Ketidakseragaman dalam pengolahan koleksi seperti: penentuan tajuk subyek, tajuk entri utama, dan penentuan nomor klasifikasi merupakan masalah dan pekerjaan rumah yang harus segera diselesaikan bersama sebagai bentuk tanggung jawab profesi".

Sedangkan Informan 5 berpendapat bahwa "Selama ini program-program dan kegiatan FP UGM tidak fokus pada tugas pokok fungsi, padahal pustakawan bekerja dalam TUPOKSI. Ada permasalahan serius dalam realisasi TUPOKSI pustakawan UGM, yaitu dalam manajemen koleksi. Tidak ada standar atau pedoman pengelolaan koleksi dan kebijakan umum pengadaan yang harus secara konsisten ditaati oleh seluruh perpustakaan di lingkungan UGM. Output kerja yang seperti ini menunjukkan dan dapat menjadi indikator seperti apa sebenarnya tingkat profesionalisme Pustakawan UGM"

\section{c. Analisis Peran FP UGM dalam mengembangkan Profesionalisme Pustakawan Berdasarkan SKKNI}

Berdasarkan metode penelitian yang kami pergunakan, maka proses analisis data dilakukan dengan cara melakukan observasi 
terhadap laporan pertanggungjawaban tiga periode terakhir kepengurusan FP, yaitu kepengurusan periode 2011 - 2013, 2013 2015, 2015 - 2018. Pada laporan tersebut, kami melakukan analisis dan memasukkan data kedalam tabel analisis berdasarkan SKKNI bidang Perpustakaan dan kemudian kami deskripsikan serta konfirmasi dengan Pengurus FP.

Adapun tujuan dari observasi yang kami lakukan terhadap laporan pertanggungjawaban FP UGM ini adalah untuk mengetahui tentang konsep pengembangan yang dimiliki oleh FP pada kepengerusan tiga periode terakhir dalam meningkatkan profesionalisme dan kompetensi para anggotanya. Untuk memperkuat data, wawancara kami lakukan kepada beberapa informan dari 3 (tiga) periode kepengurusan tersebut.

SKKNI bidang Perpustakaan adalah suatu sumber pedoman yang telah dijadikan sebagai standarisasi penilaian terhadap kinerja dan tingkat profesionalisme pustakawan yang mana didalamnya mengatur tentang standar profesionalisme para pustakawan, hal ini dikarenakan profesionalisme pustakawan haruslah tercermin pada kemampuan (pengetahuan, pengalaman, keterampilan) dalam mengelola dan mengembangkan pelaksanaan pekerjaan di bidang kepustakawanan serta kegiatan terkait lainnya secara mandiri.

Ini artinya bahwa di dalam melaksanakan tugas kepustakawanannya secara profesional maka seorang Pustakawan harus memiliki sejumlah kompetensi, yaitu kemampuan untuk untuk melaksanakan suatu tugas atau pekerjaan yang didasari atas pengetahuan, keterampilan dan sikap sesuai dengan unjuk kerja yang dipersyaratkan. Pustakawan profesional dituntut menguasai bidang ilmu kepustakawanan, memiliki keterampilan dalam melaksanakan tugas/ pekerjaan kepustakawanan, melaksanakan tugas/ pekerjaannya dilandasi oleh sikap dan kepribadian menarik, demi mencapai kepuasaan pengguna (Saleh, 2004).
Kompetensi yang tertuang dalam SKKNI dikodekan sebagai berikut:

Tabel. 2. Kode Kompetensi dalam SKKNI KODE KOMPETENSI

\begin{tabular}{|c|c|}
\hline & \\
\hline KU-1 & Mengoperasikan Komputer Dasar \\
\hline KU-2 & Menyusun Rencana Kerja Perpustakaan \\
\hline KU-3 & Membuat Laporan Kerja Perpustakaan \\
\hline $\mathrm{KI}-1$ & Melakukan Seleksi Bahan Perpustakaan \\
\hline $\mathrm{KI}-2$ & Melakunan Pengadaan Bahan Pustaka \\
\hline $\mathrm{KI}-3$ & Melakukan Pengkatalogan Deskripstif \\
\hline $\mathrm{KI}-4$ & Melakukan Pengkatalogan Subyek \\
\hline $\mathrm{KI}-5$ & Melakukan Perawatan Bahan Pustaka \\
\hline $\mathrm{KI}-6$ & Melakukan Layanan Sirkulasi \\
\hline KI-7 & Melakukan Layanan Referensi \\
\hline $\mathrm{KI}-8$ & $\begin{array}{l}\text { Melakukan Penelusuran Informasi } \\
\text { Sederhana }\end{array}$ \\
\hline KI-9 & Melakukan Promosi Perpustakaan \\
\hline KI-10 & Melakukan Kegiatan Literasi Informasi \\
\hline KI-11 & $\begin{array}{l}\text { Memanfaatkan Jaringan Internet untuk } \\
\text { Layanan Perpustakaan }\end{array}$ \\
\hline KK-1 & $\begin{array}{l}\text { Merancang Tata Ruang dan Perabot } \\
\text { Perpustakaan }\end{array}$ \\
\hline KK-2 & Melakukan Perbaikan Bahan Perpustakaan \\
\hline KK-3 & Membuat Literatur Sekunder \\
\hline KK-4 & $\begin{array}{l}\text { Melakukan Penelusuran Informasi } \\
\text { Kompleks }\end{array}$ \\
\hline KK-5 & Melakukan Kajian Perpustakaan \\
\hline KK-6 & Membuat Karya Tulis Ilmiah \\
\hline KKC-1 & $\begin{array}{l}\text { Mengumpulkan, Menganalisis dan } \\
\text { mengorganisasikan informasi }\end{array}$ \\
\hline KKC-2 & Mengkomunikasikan informasi dan ide-ide \\
\hline $\mathrm{KKC}-3$ & $\begin{array}{l}\text { Merencanakan dan mengorganisasikan } \\
\text { kegiatan }\end{array}$ \\
\hline $\mathrm{KKC}-4$ & $\begin{array}{l}\text { Bekerjasama dengan orang lain dan } \\
\text { kelompok. }\end{array}$ \\
\hline KKC-5 & $\begin{array}{l}\text { Menggunakan gagasan secara matematis } \\
\text { dan teknis }\end{array}$ \\
\hline KKC-6 & Memecahkan masalah \\
\hline KKC-7 & Menggunakan teknologi \\
\hline
\end{tabular}

Atas dasar analisa terhadap kegiatan yang telah dilakukan oleh para pengurus pada setiap periode kepengurusan, korelasi, dan daya akomodatif kegiatan terhadap standar kompetensi berdasarkan SKKNI, dapat ditarik kesimpulan bahwa peran FP UGM dalam pengembangan profesionalisme Pustakawan di UGM sudah dilaksanakan dengan baik dan mendukung empat kompetensi dalam SKKNI. Dan dari 60 kegiatan yang telah dilaksanakan oleh setiap periode kepengurusan, kompetensi inti KI-10 (Melakukan Kegiatan Literasi Informasi) mendapatkan capaian kegiatan dengan frekwensi capaian terbanyak. Frekwensi kegiatan FP UGM terhadap kompetensi pustakawan berdasarkan SKKNI terlihat pada grafik 1. 
Grafik. 1. Statistik Analisis Peran FP UGM

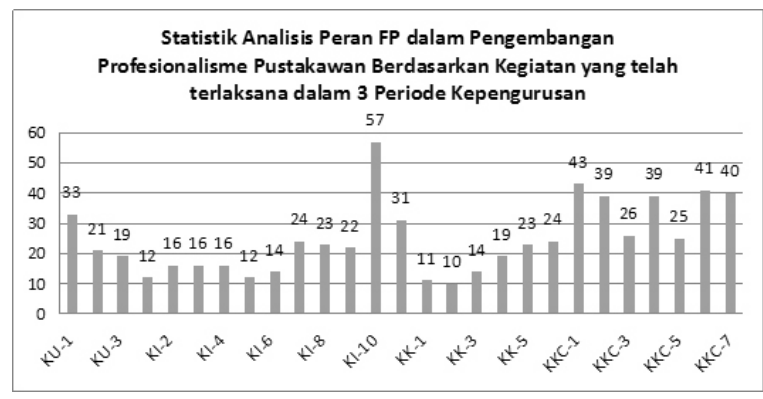

\section{d. Analisis Hambatan anggota}

Berdasarkan hasil wawancara terhadap anggota FP UGM, secara keseluruhan informan menyatakan bahwa kegiatan yang dilaksanakan FP memiliki banyak manfaat khususnya bagi pengembangan profesionalisme pustakawan di UGM. Akan tetapi hal tersebut tidak secara keseluruhan menghilangkan hambatanhambatan yang dihadapi oleh masing-masing anggota untuk turut aktif melibatkan diri dalam setiap kegiatan FP.

Adapun berdasarkan hasil wawancara kepada informan, ditemukan bahwa masih banyak program-program dari pengurus FP UGM yang belum mengakomodir kebutuhan pustakawan akan kemampuan dan skills yang dapat diimplementasikan di tugas keseharian (TUPOKSI). Bahkan kegiatan terkait informasi-informasi dan pengetahuanpengetahuan tentang kompetensi inti pustakawan belum tersentuh sama sekali, sebagai contoh dalam manajemen koleksi, Perpustakaan UGM belum memiliki pedoman atau standar baku yang digunakan dalam pengelolaan pustaka (resources) baik cetak maupun digital. Ketidakseragaman dalam pengolahan koleksi seperti: penentuan tajuk subyek, tajuk entri utama, dan penentuan nomor klasifikasi merupakan permasalahan dalam manajemen koleksi dan menjadi pekerjaan rumah yang harus segera diselesaikan bersama sebagai bentuk tanggung jawab profesi.

Hal lain yang menjadi hambatan anggota untuk aktif dalam forum adalah kegiatan FP UGM dilaksanakan pada saat jam kerja, sehingga anggota tidak mungkin untuk meninggalkan kewajiban utamanya demi mengikuti kegiatan-kegiatan yang dilaksanakan oleh pengurus FP UGM.
Atas dasar informasi diatas, hambatan yang dialami oleh Pengurus FP UGM dalam mengembangkan profesionalisme Pustakawan di UGM secara garis besar adalah:

1. Agenda kegiatan yang dilakukan FP terkadang berbenturan dengan kegiatan atau tugas dinas lain. Pelaksanaan kegiatan FP dilakukan pada jam kerja menyebabkan minat dan keinginan anggota untuk mengikuti kegiatan yang diadakan oleh FP menjadi sangat minim karena berbenturan dengan tugas dinas lain. Namun disini Pengurus FP tetap mengakomodasinya dengan menyampaikan setiap materi kegiatan dengan mendokumentasikan melalui blog FP UGM maupun PLO (paperless office). Selain itu ada pendampingan atau mentoring dalam kelompok-kelompok pustakawan yang pada hakikatnya untuk meningkatkan kecakapan dan kemampuan kepustakawanan, misalnya kelompok menulis. Kegiatan tersebut dapat dilaksanakan untuk mengatasi para pustakawan yang berbenturan hadir datang kegiatan FP dikarenakan kegiatan ini berjalan secara berkelanjutan. Kegiatan pendampingan diharapkan dapat menghasilkan produk nyata seperti artikel populer pustakawan, karya ilmiah pustakawan yang kemudian dengan adanya pendampingan tersebut proses belajar dan proses peningkatan diri akan berujung pada peningkatan profesionalisme dan kompetensi anggota FP. Selain itu pendampingan yang dilaksanakan secara insidental sesuai permintaan anggota perlu diinisiasi dan disebarkan secara terbuka oleh Pengurus FP untuk mengatasi waktu pelaksanaan yang berbenturan dengan tugas dinas lain. Kalaupun tema pendampingan atau mentoring belum dikuasai atau melebihi kemampuan dan kapasitas Pengurus FP, Pengurus bisa mencari Narasumber yang lebih expert dibidang tertentu sesuai permintaan anggota.

2. Konten kegiatan yang dilakukan FP tidak sesuai dengan kebutuhan anggota FP. Berdasarkan hasil wawancara dengan pengurus FP UGM dilapangan upaya untuk 
pengembangan profesionalisme Pustakawan di UGM sudah dilakukan dari setiap periode kepengurusan dengan menyelenggarakan kegiatan-kegiatan melalui proses perencanaan dan pemetaan sesuai dengan kebutuhan dan problematikaproblematika yang dimiliki anggota, prencanaan dan pemetaan dilakukan dengan menghimpun berbagai aspirasi dan usulan anggota yang disampaikan pengurus FP (paperless office). Perencanaan dan pemetaan, juga melewati pembahasan pada level pengurus FP. Pemetaan program atau kegiatan mencakup: kegiatan ilmiah, kompetensi keseharian, kompetensi layanan, pengolahan, dan kegiatan-kegiatan lain yang mendukung karir dan berkaitan dengan profesi dan sosialisasi akan informasi terkini dan perkembangan kepustakawanan tetap diakomodir. Kegiatan diselenggarakan dengan format diskusi, seminar maupun sharing, akan tetapi realisasinya tidak selalu sesuai rencana, karena perkembangan kepustakawanan begitu dinamis. Namun demikian walaupun FP telah melaukan proses pemetaan dan perencanaan sebaiknya realisasinya harus diperhatikan dan dilaksanakan sesuai jadwal perencanaan yang sudah dibuat, agar kedepan anggota tidak kecewa. Di samping itu konten kegiatan tidak hanya berfokus pada perkembangan informasi terkini tentang kepustakawanan tetapi menyentuh ke kegiatan yang core nya atau TUPOKSI nya tentang kepustakawanan dan DUPAK Pustakawan. Misalnya secara formal dibentuk mentoring untuk kelas penulisan, kelas kajian/ penelitian (metodologi dan statistik), kelas presntasi, kelas bahasa inggris, kelas penulisan di blog agar membudayakan menulis, karena dengan blog FP dapat memotivasi Pustakawan lain untuk aktif menulis. Selain itu FP juga dapat menjadi media dalam pembuatan panduan angka kredit agar persepsi antara tim penilai dengan pustakawan sama.

3. Konten kegiatan yang dilaksanakan FP bisa dipelajari sendiri sehingga anggota menganggap tidak perlu dilakukannya pertemuan atau tatap muka dengan pengurus ataupun anggota lainnya.

4. FP telah melakukan upaya dan langkahlangkah pendekatan kepada anggota untuk mendorong berhasilnya suatu program melalui pendekatan-pendekatan dan pengkondisian-pengkondisian agar anggota nyaman dengan keberadaan FP. Akan tetapi untuk mengatasi hambatan mengenai konten kegiatan yang bisa dipelajari sendiri tersebut sebaiknya Pengurus FP UGM perlu untuk menyusun modul modul apa saja yg sekiranya dapat di pelajari sendiri oleh para anggota tentunya beserta panduan-panduan pembelajarannya. Sehingga Pengurus bisa fokus pada kegiatan utama FP UGM yaitu tema kegiatan yang lebih cenderung untuk membahas dan menyelesaikan permasalahan permasalahan nyata yang dihadapi oleh anggota FP UGM di setiap Perpustakaan Fakultasnya.

\section{E. KESIMPULAN}

Berdasarkan hasil penelitian dan pembahasan, maka dapat ditarik kesimpulan sebagai berikut:

a. Peran FP UGM dalam pengembangan profesionalisme Pustakawan di lingkungan UGM sudah dilaksanakan dengan baik dan mendukung empat kompetensi dalam SKKNI. Namun dari 60 kegiatan yang telah dilaksanakan kompetensi inti KI-10 (melakukan kegiatan literasi informasi) mendapatkan capaian terbanyak.

b. Hambatan para Pustakawan untuk turut aktif melibatkan diri dalam FP UGM yaitu agenda kegiatan terkadang berbenturan dengan kegiatan atau tugas dinas lain, konten kegiatan tidak sesuai dengan kebutuhan anggota, serta konten bisa dipelajari sendiri

Berdasarkan kesimpulan di atas, maka diajukan saran sebagai berikut:

a. Perlu adanya program kegiatan yang mengakomodir semua kompetensi dalam SKKNI dan dibuatnya SOP untuk setiap kegiatan yang dilakukan.

b. Perlu adanya inisiasi pendampingan atau 
mentoring dari kelompok-kelompok pustakawan untuk meningkatkan kecakapan dan kemampuan kepustakawanan yang diprakarsai oleh pengurus FP UGM secara berkelanjutan dan disebarkan secara terbuka oleh Pengurus FP UGM.

c. Realisasi kegiatan yang sudah melalui tahap pemetaan dan perencanaan diperhatikan dan dilaksanakan sesuai jadwal perencanaan yang sudah dibuat

d. Menyelenggarakan kegiatan yang menyentuh TUPOKSI kepustakawanan dan membantu membahas permasalahan permasalahan nyata yang dihadapi oleh anggota, membentuk media yang bersifat pendampingan/ pembimbingan/ pembinaan bagi Pustakawan yang DUPAK nya terlambat dan kedua belah pihak harus aktif, serta menjadi media dalam pembuatan panduan angka kredit agar persepsi antara tim penilai dengan Pustakawan sama

e. Perlu menyusun modul dengan tema yang dapat di pelajari sendiri oleh para anggota FP UGM beserta panduan-panduan pembelajarannya serta dalam setiap periode kepengurusan bisa melakukan kegiatan literasi informasi ke masyarakat dan mempunyai perpustakaan binaan sebagai bentuk pengabdian kepada masyarakat umum.

\section{DAFTAR PUSTAKA}

Departemen Pendidikan dan Kebudayaan. (2011). Kamus Besar Bahasa Indonesia. Jakarta: Balai Pustaka.

Departemen Pendidikan dan Kebudayaan. (1989). Pola Pengembangan Sekolah Menengah Kejuruan Seutuhnya. Malang: Dikmenum.

Forum Pustakawan. (2013). Laporan Pertanggungjawaban Periode 2011 - 2013, Yogyakarta: Perpustakaan Universitas Gadjah Mada

Forum Pustakawan (2015). Laporan Pertanggungjawaban Perioide 2013 - 2015, Yogyakarta: Perpustakaan Universitas Gadjah Mada
Forum Pustakawan. (2016). Arsip Laporan Pertanggungjawaban Sementara Perioide 2015 - 2018, Yogyakarta: Perpustakaan Universitas Gadjah Mada

Istiana, Purwani. (2011). Meningkatkan Profesionalisme Sebagai Langkah Awal Peningkatan Citra Positif Pustakawan. Media Pustakawan, Vol. 18 No. $1 \& 2$, 5051.

Kepala Perpustakaan Universitas Gadjah Mada (2011). Surat Keputusan Pengangkatan Pengurus Forum Pustakawan UGM. Yogyakarta: Perpustakaan Universitas Gadjah Mada

Kepala Perpustakaan Universitas Gadjah Mada (2013). Surat Keputusan Pengangkatan Pengurus Forum Pustakawan UGM. Yogyakarta: Perpustakaan Universitas Gadjah Mada

Kepala Perpustakaan Universitas Gadjah Mada (2015). Surat Keputusan Pengangkatan Pengurus Forum Pustakawan UGM. Yogyakarta: Perpustakaan Universitas Gadjah Mada.

Mahmudi. (2010). Manajemen Kinerja Sektor Publik. Yogyakarta: UPP STIMYKPN.

Mahsun, M. (2006). Pengukuran Kinerja Sektor Pelayanan Publik. Yogyakarta: BPFE.

Nashihuddin, W., \& Aulianto, D. R. (2015). Strategi Peningkatan Kompetensi dan Profesionalisme Pustakwan. Jurnal PerpustakaanPertanian, vol. 24 no.2, 5354.

Pasolong, H. (2010). Teori administrasi publik. Bandung: Alfabeta.

Perpustakaan IPB. (2009). Rencana Program, Kegiatan Dan Anggaran Penyelenggaraan Dan Pembangunan Pendidikan Tinggi (RPKAP3T) IPB Tahun 2009. Bogor: Perpustakaan IPB.

Purwanti, N. (2016). Peran Perpustakaan dalam Mendukung Universitas Gadjah Mada menjadi Perguruan Tinggi Bereputasi yang Mengakar Kuat Menjulang Tinggi. Yogyakarta: Perpustakaan UGM.

Republik Indonesia. (2007). Undang - Undang Nomor 43 Tahun 2007 tentang Perpustakaan. Jakarta: CV. Tamita Utama. 
Republik Indonesia. (2012). Keputusan Menteri Tenaga Kerja dan Transmigrasi Republik Indonesia Nomor 83 Tahun 2012. Jakarta: Perpustakaan Nasional RI.

Robbins, S. P., \& Judge, T. A. (2008). Perilaku Organisasi I : Organizational Behavior. Jakarta: Salemba Empat.

Sanusi, A. e. (1991). Studi Pengembangan Model Pendidikan Profesional Tenaga kependidika. Bandung: IKIP Bandung.

Sugiyono. (2008). Memahami Penelitian Kualitatif. Bandung: CV.Alfabeta.
Sulistiyani, A. T., \& Rosidah.(2009). Manajemen Sumber Daya Manusia. Yogyakarta: Graha Ilmu.

Sulistyo-Basuki. (2004). Pengantar Ilmu Perpustakaan. Jakarta: Gramedia Pustaka Utama.

Wijayati, K. (2013). Perancangan Dan Pembuatan Forum Diskusi Berbasis Web. Yogyakarta: Sekolah Tinggi Manajemen Informatika Dan Komputer. 